\title{
Dietary Supplementation with Microalgae (Schizochytrium sp.) Improves the Antioxidant Status, Fatty Acids Profiles and Volatile Compounds of Beef
}

\author{
Chenchen Xu ${ }^{1,2}$, Shou Zhang ${ }^{3}$, Baozhong Sun ${ }^{1}$, Peng Xie ${ }^{1}$, Xiaochang Liu ${ }^{1}$, Lan Chang ${ }^{3}$, Fushan Lu ${ }^{3}$ \\ and Songshan Zhang ${ }^{1, *}$ \\ 1 Institute of Animal Sciences, Chinese Academy of Agricultural Sciences, Beijing 100193, China; \\ xuchenchen@caas.cn (C.X.); sunbaozhong@caas.cn (B.S.); xiepeng@caas.cn (P.X.); liuxiaochang@caas.cn (X.L.) \\ 2 China Meat Research Center, Beijing Academy of Food Sciences, Beijing 100068, China \\ 3 College of Agriculture and Animal Husbandry, Qinghai University, Xining 810016, China; \\ 1987990012@qhu.edu.cn (S.Z.); 1987990008@qhu.edu.cn (L.C.); 1993990012@qhu.edu.cn (F.L.) \\ * Correspondence: zhangsongshan@caas.cn
}

check for updates

Citation: Xu, C.; Zhang, S.; Sun, B.; Xie, P.; Liu, X.; Chang, L.; Lu, F.; Zhang, S. Dietary Supplementation with Microalgae (Schizochytrium sp.) Improves the Antioxidant Status, Fatty Acids Profiles and Volatile Compounds of Beef. Animals 2021, 11, 3517. https://doi.org/10.3390/ ani11123517

Academic Editors: Antonio Natalello and Raffaella Rossi

Received: 12 October 2021

Accepted: 7 December 2021

Published: 10 December 2021

Publisher's Note: MDPI stays neutral with regard to jurisdictional claims in published maps and institutional affiliations.

Copyright: (c) 2021 by the authors. Licensee MDPI, Basel, Switzerland. This article is an open access article distributed under the terms and conditions of the Creative Commons Attribution (CC BY) license (https:/ / creativecommons.org/licenses/by/ $4.0 /)$.
Simple Summary: This study evaluated the effects of Schizochytrium sp., as a promising feed additive, on the antioxidant enzyme activity, physicochemical quality, fatty acid composition and volatile compounds of beef. The results revealed that Schizochytrium could improve the antioxidant capacity of beef and increase the nutritional value, which was related to the abundant docosahexaenoic acid (DHA) found in Schizochytrium. Our current research results provide guidance for the development of environmentally friendly diet additives.

Abstract: The purpose of this study was to evaluate the effects of dietary supplementation with microalgae (Schizochytrium sp.) containing docosahexaenoic acid (DHA) on the antioxidant enzyme activity, physicochemical quality, fatty acid composition and volatile compounds of beef meat. Eighteen male Qaidamford cattle were randomly allocated into three treatments $(n=6)$ : no microalgae supplementation (Control group, C), $100 \mathrm{~g}$ microalgae supplementation per bull per day (FD1), and $200 \mathrm{~g}$ microalgae supplementation per bull per day (FD2), and fed for 49 days before slaughter. The results showed that, compared with the $C$ group, the addition of DHA-rich microalgae to the diet could significantly increase the total antioxidant capacity (T-AOC) in meat. In the FD2 group, it was found that the concentration of glutathione peroxidase (GSH-Px) was significantly higher than that of the control group $(p<0.05)$. DHA-rich microalgae supplementation increased polyunsaturated fatty acid (PUFA), eicosapentaenoic acid (EPA; C20:5 n-6), DHA, EPA + DHA, and n-3 PUFA and reduced n-6:n-3 fatty acid ratio. Twenty-four volatile compounds identified in beef were mainly aldehydes, alcohols and ketones from the fingerprints. The contents of short-chain fatty aldehydes, 1-octen-3-ol and 2-pentylfuran, were higher in the FD2 group than in the other two groups. The microalgae diet improved the sensory attribute score of beef. The results demonstrated that dietary supplementation of DHA-rich microalgae improved the antioxidant status, increased the deposition of DHA and enhanced the characteristic flavor of beef.

Keywords: microalgae; docosahexaenoic acid; antioxidant status; n-3 polyunsaturated fatty acids; volatile compounds

\section{Introduction}

The beef industry has become one of the fastest-growing industries in China's animal husbandry [1]. Beef contributes high-quality protein to consumers. However, due to the biohydrogenation of n-3 polyunsaturated fatty acids (n-3 PUFA) in the ruminant rumen [2], the n-3 PUFA in beef is insufficient to meet the needs of human health [3]. It is well known that more n-3 PUFA, eicosapentaenoic acid (EPA) and docosahexaenoic acid (DHA) 
ingested in the diet, has health benefits for the control of human cardiovascular and cerebrovascular diseases [4]. The n-3 PUFA is an "essential" nutrient for the human body because humans cannot synthesize them [5]. Although $\alpha$-linolenic acid (ALA) could be converted into EPA and DHA in the human body, it seems that the degree of conversion is limited, and the efficiency is extremely low [6,7]. Thus, it is an effective strategy to increase the concentration of DHA and EPA in beef by feeding the cattle n-3 PUFA-enriched fish oil or microalgae.

Researchers found that after animals were fed fish oil, the oxidative stability of the meat was reduced and was accompanied by off-odors, which was caused by the oxidation of lipids in the meat during shelf life [8-10]. Another alternative approach is to add marine microalgae into animal diets. The advantage of this approach would be that microalgae may be photosynthetically autotrophic and grow fast [11,12]. They are used as a source of animal feed [13], thereby solving the problem of sustainability of supply [14]. In addition to the high content of DHA, microalgae also contain antioxidants such as $\beta$-carotenoids, vitamin $E$ and vitamin A [15], which can enhance the immune response [16], antioxidant activity [17] and antibacterial effect [18] of animals, and ensure that animals remain healthy. Schizochytrium is a kind of thraustochytrid microalgae, and is the source of DHA in the marine food chain [19]. The addition of Schizochytrium in animal diets has been proven to improve the quality of meat and increase the content of n-3 PUFA [20-23]. Nevertheless, information on the relationship between microalgae and volatile compounds has not been reported.

We hypothesized that the difference in antioxidant status and volatile compounds in beef after slaughter could be explained by the level of Schizochytrium addition. Therefore, the purpose of this study is to determine the influence of a dietary DHA-rich microalgae concentration through the determination of antioxidant capacity, physical indicators, fatty acid composition and volatile compounds.

\section{Materials and Methods}

\subsection{Animals, Experimental Design and Diets}

A total of 18 male Qaidamford cattle (24 months old, weighing $345.42 \pm 12.49 \mathrm{~kg}$ ) were randomly allocated to three experimental groups with 6 bulls of each, and assigned to individual pens $(3 \times 2.5 \mathrm{~m})$. The experiment lasted for 49 days. This research was conducted in Qinghai Jinsui Animal Husbandry Co., Ltd. (Haixi Mongolian and Tibetan Autonomous Prefecture, Delingha City, China). All animals were fed twice daily at 08:00 h and 17:00 h. Water was provided freely. The experimental groups were as follows: (1) C (control group, a basal diet without microalgae powder supplementation), (2) FD1 (100 g microalgae powder per bull per day of basal diet) and (3) FD2 (200 g microalgae powder per bull per day of basal diet). The bulls first received the concentrate mixed with the Schizochytrium sp. powder and then ingested the dietary roughage mixed with oat hay and alfalfa hay. The ratio of forage to concentrate was 60:40. The ingredient and chemical composition of the basal diets are presented in Table 1.

Table 1. Ingredients and chemical compositions of experimental diets.

\begin{tabular}{|c|c|c|c|}
\hline \multicolumn{2}{|l|}{ Ingredients (g/kg Fed Basis) } & \multicolumn{2}{|c|}{ Chemical Composition (g/kg DM Basis) $^{2}$} \\
\hline Oat Hay & 200 & Crude protein & 122.0 \\
\hline Alfalfa hay & 400 & Neutral detergent fiber & 315.5 \\
\hline Corn & 216 & Acid detergent fiber & 169.0 \\
\hline Wheat bran & 24 & Calcium & 5.2 \\
\hline Wheat distillers dried grains with solubles & 20 & Phosphorus & 4.0 \\
\hline Soybean meal & 48 & Net energy/(MJ/kg) ${ }^{3}$ & 5.3 \\
\hline Rapeseed meal & 40 & & \\
\hline Cottonseed meal & 16 & & \\
\hline Jujube powder & 12 & & \\
\hline Fatty Acid Calcium & 4 & & \\
\hline
\end{tabular}


Table 1. Cont.

\begin{tabular}{|c|c|c|c|}
\hline \multicolumn{2}{|c|}{ Ingredients (g/kg Fed Basis) } & \multicolumn{2}{|c|}{ Chemical Composition (g/kg DM Basis) $^{2}$} \\
\hline Sodium Chloride & 4 & & \\
\hline Mineral and vitamin premix ${ }^{1}$ & 16 & & \\
\hline \multicolumn{4}{|c|}{ Fatty Acids, mg/g Diet } \\
\hline C14:0 & 0.13 & C16:1 & 0.10 \\
\hline C15:0 & 0.02 & C18:1 n-9 & 12.08 \\
\hline $\mathrm{C} 16: 0$ & 9.19 & C18:2 n-6 & 16.44 \\
\hline $\mathrm{C} 17: 0$ & 0.05 & C18:3 n-3 (ALA) & 0.94 \\
\hline C18:0 & 1.03 & C20:1 & 0.16 \\
\hline C20:0 & 0.17 & C20:2 n-6 & 0.01 \\
\hline C21:0 & 0.02 & C20:5 n-3 (EPA) & 0.02 \\
\hline $\mathrm{C} 22: 0$ & 0.10 & & \\
\hline
\end{tabular}

DM, dry matter; ALA, $\alpha$-linolenic acid; EPA, eicosapentaenoic acid. ${ }^{1}$ Vitamin and mineral premix supplied each $\mathrm{kg}$ of feeds with Vitamin A 4000 IU; Vitamin D3 300 IU; Vitamin E 45 IU; Cu 8 mg; Fe 48 mg; Mn 30 mg; Zn 25 mg; I 0.2 mg; Se 0.3 mg; Co 0.12 mg. ${ }^{2}$ Analyzed value.

${ }^{3}$ Calculated value.

The crude protein, calcium and phosphorus contents of the experimental diet were analyzed following the Association of Official Analytical Chemists' (AOAC) methods [24]. The concentrations of neutral detergent fiber and acid detergent fiber were calculated as described by Van Soest et al. [25]. The fatty acid (FA) profiles of the experimental diet were determined at the Ministry of Agriculture Feed Industry Center (College of Animal Science and Technology, China Agricultural University, Beijing, China), and analyzed by gas chromatography (Agilent 6890 Series, Agilent Technologies, Avondale, Palo Alto, CA, USA) equipped with a capillary column (CP-Sil 88 column, $0.25 \mathrm{~mm} \times 50 \mathrm{~m}$ ) according to the procedure described by Li et al. [26]. The FA composition of the Schizochytrium sp. used in the diets is shown in Table 2. The commercial Schizochytrium sp. powder (21.0\% protein, $41.2 \%$ fat, $2.8 \%$ ash, and $2.3 \%$ moisture) was purchased from Xi'an Xiaocao Biotechnology Co., Ltd. (Xi'an, China).

Table 2. The fatty acid composition of Schizochytrium sp. used in diets.

\begin{tabular}{cc}
\hline \multicolumn{3}{c}{ Fatty Acid, mg/g Dried Powder } \\
\hline C14:0 $15: 0$ & 1.96 \\
C16:0 $17: 0$ & 5.07 \\
C18:0 & 73.04 \\
C20:0 $21: 0$ & 4.33 \\
C22:0 & 3.26 \\
C23:0 & 0.84 \\
C16:1 & 0.02 \\
C18:1 n-9 & 0.53 \\
C20:1 & 0.11 \\
C18:2 n-6 $20: 2$ n-6 & 0.56 \\
C18:3 n-3 (ALA) & 0.03 \\
C20:3 n-6 & 0.06 \\
C20:4 n-6 & 0.15 \\
C20:5 n-3 (EPA) & 0.24 \\
C22:6 n-3 (DHA) & 0.97 \\
\hline
\end{tabular}

ALA, $\alpha$-linolenic acid; EPA, eicosapentaenoic acid; DHA, docosahexaenoic acid.

\subsection{Sample Collection}

All animals were weighed $(393.37 \pm 23.53 \mathrm{~kg}$ for the C group, $408.50 \pm 24.72 \mathrm{~kg}$ for the FD1 group, and $403.25 \pm 15.94 \mathrm{~kg}$ for the FD2 group) and transported to commercial 
slaughterhouses for slaughter to facilitate sample collection and measurement after the end of the feeding trial. In order to better simulate the quality of beef consumed by residents in the Qinghai-Tibet Plateau, we chose $48 \mathrm{~h}$ after slaughter as the sampling time. After chilling for $48 \mathrm{~h}$ at $4{ }^{\circ} \mathrm{C}$, the $\mathrm{M}$. longissimus lumborum (LL) muscle sample was taken from the left side of each carcass and transported to the laboratory with a portable cooler. All beef samples were trimmed with visible fat and connective tissue before vacuum packaging and stored at $-80^{\circ} \mathrm{C}$ for further analysis within two weeks.

\subsection{Analysis of Antioxidant Enzymes Activity and Lipid Oxidation}

All samples were thawed at $4{ }^{\circ} \mathrm{C}$ for $24 \mathrm{~h}$ before analysis. One gram of meat was mixed with cold phosphate-buffered saline $(0.06 \mathrm{~mol} / \mathrm{L}, \mathrm{pH} 7.4)$ at a ratio of 1:10 (weight/volume, $w / v$ ) and then homogenized with Ultra Turrax T25 (IKA, Braun, Kronberg, Germany) homogenizer. After centrifugation at $4000 \mathrm{rpm}$ and $4{ }^{\circ} \mathrm{C}$ for $10 \mathrm{~min}$, the supernatant was collected to determine the protein content and antioxidant enzyme activity. Protein concentration, total antioxidant capacity (T-AOC), superoxide dismutase (SOD), glutathione peroxidase (GSH-Px) levels and thiobarbituric acid reactive substances (TBARS) level were measured using commercial assay kits (Nanjing Jiancheng Bioengineering Institute, Nanjing, China) by a spectrophotometer (Spectral Instrument Co. Ltd., Shanghai, China). The results of T-AOC, SOD and GSH-Px were expressed in $\mathrm{U} / \mathrm{mg}$ protein, and the absorbance was measured at $520 \mathrm{~nm}, 550 \mathrm{~nm}$ and $412 \mathrm{~nm}$, respectively. Lipid oxidation was evaluated using the TBARS value. The absorbance was measured at $532 \mathrm{~nm}$. Results were expressed as mg malonaldehyde (MDA) $/ \mathrm{kg}$ meat.

\subsection{Meat Physicochemical Quality Characteristics Analysis}

\subsection{1. $\mathrm{pH}$ and Color Measurement}

The $\mathrm{pH}$ values were measured with a Testo $205 \mathrm{pH}$ meter (Lenzkirch, Germany) calibrated with $\mathrm{pH} 4$ and 7 standard buffer solutions. The average value obtained by inserting electrodes into three different points of each sample was used for statistical analysis.

The thawed LL muscle sample was bloomed for $45 \mathrm{~min}$ before measurement. The surface color of meat was measured with a portable CR-400 Colorimeter (Minolta Inc., Osaka, Japan), using an illuminant D65 and a 2-degree standard observer. Color parameters $L^{*}$ (lightness), $a^{*}$ (redness) and $b^{*}$ (yellowness) were measured at different positions on the surface of each sample with triplicate measurements, and the average values were calculated. Chroma $\left(C^{*}\right)$ and hue angle $\left(H^{*}\right)$ were evaluated by the following equations:

$$
\begin{gathered}
C^{*}=\left(a^{* 2}+b^{* 2}\right)^{1 / 2}, \\
H^{*}=\arctan \left(b^{*} / a^{*}\right) \times(180 / \pi)
\end{gathered}
$$

\subsubsection{Drip Loss and Cooking Loss Determination}

Drip loss. Drip loss was estimated according to the protocol followed by Honikel [27]. Approximately $60 \mathrm{~g}$ of each meat sample was weighed (W1) and then suspended in an inflated polyethylene bag at $4{ }^{\circ} \mathrm{C}$ without any contact with the bag. After $24 \mathrm{~h}$, the sample was taken out of the bag, gently wiped off the residual surface drip, and then weighed (W2). Drip loss was calculated as the percentage ratio of the initial weight using the following formula:

$$
\text { Drip loss }=(\mathrm{W} 1-\mathrm{W} 2) / \mathrm{W} 1 \times 100 \% \text {, }
$$

Cooking Loss. Cooking loss was determined as suggested by Fabre et al. [28]. Briefly, the thawed sample was weighed (M1) and placed in a polyethylene bag, and then cooked under boiling water $\left(98 \pm 1^{\circ} \mathrm{C}\right)$ until the internal temperature reached $71^{\circ} \mathrm{C}$. The sample was taken out and weighed after cooling (M2). The cooking loss was expressed as a percentage of the initial sample weight, according to the following formula:

$$
\text { Cooking loss }=(\mathrm{M} 1-\mathrm{M} 2) / \mathrm{W} 1 \times 100 \% \text {, }
$$




\subsubsection{Proximate Composition Analysis}

Approximately $50 \mathrm{~g}$ of the minced meat sample was measured according to the method of the AOAC [24], in which protein was analyzed by a Kjeldahl K9840 analyzer (Hanon Instrument Co. Ltd., Nanjing, China), and fat was determined by an Ankom XT15 analyzer (Ankom Technology, Macedon, NY, USA). All measurements were taken in triplicates.

\subsection{Fatty Acids Analysis}

The fatty acids composition analyses were carried out according to Ponnampalam et al. [29]. In brief, the beef samples collected from each group were sliced and freeze-dried in a freeze dryer (Ningbo Xinzhi Instruments, Inc., Ningbo, China) for $72 \mathrm{~h}$. Freeze-dried samples $(0.5 \mathrm{~g})$ were ground, and then $1 \mathrm{~mL}$ internal standard (C11:0, Sigma Aldrich Pty Ltd., St. Louis, MI, USA) was added to muscle samples. The contents were hydrolyzed with $0.7 \mathrm{~mL}$ of $10 \mathrm{~mol} / \mathrm{L}$ potassium hydroxide aqueous solution and $5.3 \mathrm{~mL}$ of methanol to form free fatty acids. Then, the contents were incubated in a water bath at $55^{\circ} \mathrm{C}$ for $1.5 \mathrm{~h}$ by vortex mixing and mixed with $0.58 \mathrm{~mL}$ of $24 \mathrm{~N}$ sulfuric acid $\left(\mathrm{H}_{2} \mathrm{SO}_{4}\right)$ in water and cooled to room temperature. After $1.5 \mathrm{~h}$ incubation, the mixture was cooled and then thoroughly mixed with $3 \mathrm{~mL}$ of hexane solvent and centrifuged. Approximately $1 \mathrm{~mL}$ supernatant (fatty acid methyl ester, FAME) was transferred into an injection vial for analysis. The FAME was determined with the gas chromatograph (GC-6890 N, Agilent Technologies, Wilmington, NC, USA), equipped with a detector (flame ionization), and separate SP-2560 type column (capillary) $(60 \mathrm{~m} \times 2.5 \mathrm{~cm} \times 0.25 \mu \mathrm{m}$, Supelco Inc., Bellefonte, PA, USA). The sample split ratio was 30:1. Gas chromatographic conditions were set according to Aldai et al. [30]. The ratio of retention time to the FAME standard mixture (FAME 37 component, Sigma-Aldrich Co., St. Louis, MI, USA) was used to identify the fatty acids.

\subsection{Volatile Compounds Analysis}

Beef samples were collected in triplicate for each group of volatile compounds. The volatile compounds were determined using a Flavorspec Gas Chromatograph-Ion Mobility Spectrometer (GC-IMS) system (GAS GmbH, Dortmund, Germany) fitted with a SE-54 capillary column $(15 \mathrm{~m} \times 0.53 \mathrm{~mm})$, and conducted with modifications according to the methods of Xu et al. [31]. Briefly, without any sample pre-treatment, two grams of fresh meat samples were weighed and placed in a $20 \mathrm{~mL}$ headspace vial and incubated at $60{ }^{\circ} \mathrm{C}$ for $20 \mathrm{~min}$. Then, $500 \mathrm{~L}$ of headspace was automatically injected into the heated syringe with a syringe at $85^{\circ} \mathrm{C}$. High-purity nitrogen was used as the carrier gas with a flow rate of $150 \mathrm{~mL} / \mathrm{min}$. The carrier gas flow rate program was set to $2 \mathrm{~mL} / \mathrm{min}$ for $2 \mathrm{~min} ; 10 \mathrm{~mL} / \mathrm{min}$ for $10 \mathrm{~min}, 100 \mathrm{~mL} / \mathrm{min}$ for $20 \mathrm{~min}$, and $150 \mathrm{~mL} / \mathrm{min}$ for $25 \mathrm{~min}$. LAV software (version 2.2.1 - G.A.S., Dortmund, Company) was used to create an area set integrating retention time (Rt) and drift time (Dt) of all markers spots and to obtain the individual signal from the topographic plot.

\subsection{Sensory Analysis}

Eight trained sensory panel members were selected according to the Chinese standard GB/T 22210-2008 (criterion for the sensory evaluation of meat and meat products). The samples were baked on a household grill at $185^{\circ} \mathrm{C}$ and removed when the core temperature reached $70^{\circ} \mathrm{C}$. After cooking, each sample was cut into $1.5 \mathrm{~cm}$ cubes, placed on a paper plate with a three-digit number and then presented to the panelists. During testing, panelists were seated in a separate compartment in the sensory room. Before proceeding to the next round of evaluation, panelists were instructed to rinse their mouths with water to clear the taste between the samples. All sensory analyses were repeated three times. The sensory attribute score of each sample was divided into 8 levels: initial juiciness $(1=$ extremely dry, $8=$ extremely juicy $)$; sustained juiciness $(1=$ extremely dry, $8=$ extremely juicy); flavor intensity ( $1=$ extremely bland, $8=$ extremely intense); off-flavor intensity $(1=$ no off-flavor, $8=$ extremely intense off-flavor $)$; initial tenderness $(0=$ extremely tough, 
8 = extremely tender); sustained tenderness $(0=$ extremely tough, $8=$ extremely tender $)$; residue $(0=$ none, $8=$ abundant $)$.

\subsection{Statistical Analysis}

All the experiments were performed in triplicate. The collected data were analyzed using one-way analysis of variance (ANOVA) by the SAS 9.2 program (SAS Institute, Cary, NC, USA). The Shapiro-Wilk test and Levene test were used to evaluate the normality of the data distribution and the homogeneity of variance. The Duncan test was used to compare mean values. Significant differences were declared at $p<0.05$.

\section{Results}

\subsection{Antioxidant Enzymes Activity and Lipid Oxidation}

Effects of dietary DHA-rich microalgae on the antioxidant enzyme activity of beef are shown in Figure 1. Compared with the control group, the activities of T-AOC in the FD1 group and FD2 group and GSH-Px in the FD1 group significantly increased $(p<0.05)$. No significant difference was observed in T-AOC and GSH-Px activities between the FD1 group and the FD2 group $(p>0.05)$. There was no significant difference in SOD activity and TBARS in all treatment groups $(p>0.05)$.
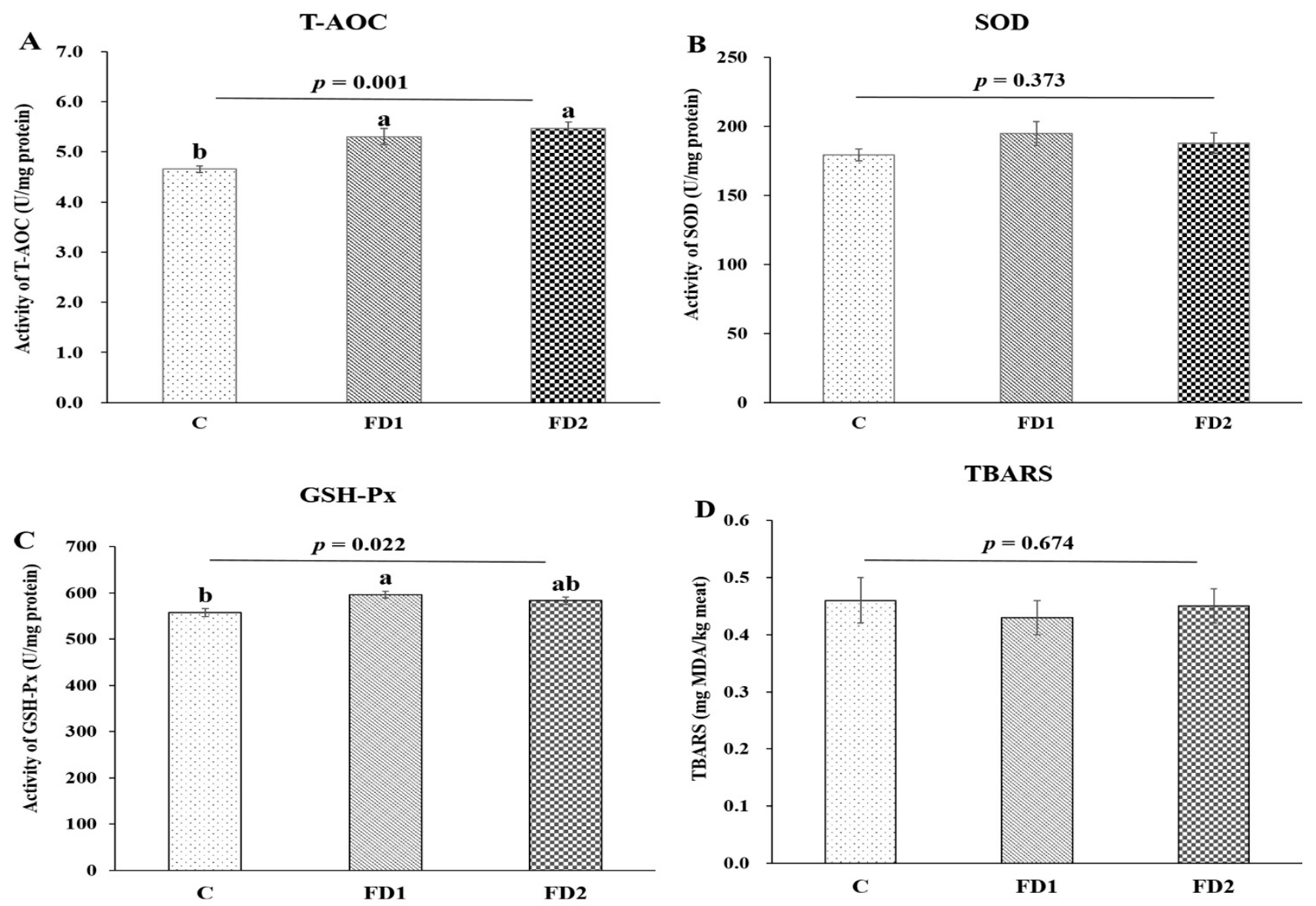

Figure 1. The influence of dietary DHA-rich microalgae on the activities of (A) T-AOC, (B) SOD, (C) GSH-Px and (D) TBARS of beef. $\mathrm{C}=$ control group; FD1 = $100 \mathrm{~g}$ microalgae powder per bull per day of basal diet; FD2 = $200 \mathrm{~g}$ microalgae powder per bull per day of basal diet. Different letters indicate significant differences due to DHA-rich microalgae supplementation levels $(p<0.05)$. 


\subsection{Meat Physicochemical Quality}

The effects of dietary DHA-rich microalgae on physicochemical meat quality are presented in Table 3. There were no differences $(p>0.05)$ in color parameters $\left(L^{*}, a^{*}, b^{*}\right.$, $\mathrm{C}^{*}$ and $\left.H^{*}\right), \mathrm{pH}$, drip loss, cooking loss and protein among the three treatments. The fat content in the FD1 and FD2 groups was significantly higher than that in the control group $(p<0.05)$.

Table 3. The influence of dietary DHA-rich microalgae on the physicochemical quality of beef meat.

\begin{tabular}{|c|c|c|c|c|c|}
\hline \multirow{2}{*}{ Item } & \multicolumn{3}{|c|}{ Treatments } & \multirow{2}{*}{ SEM } & \multirow{2}{*}{$p$-Value } \\
\hline & $\mathrm{C}$ & FD1 & FD2 & & \\
\hline$L^{*}$ & 30.07 & 29.52 & 29.73 & 1.72 & 0.66 \\
\hline$a^{*}$ & 15.17 & 14.34 & 15.73 & 2.51 & 0.64 \\
\hline$b^{*}$ & 6.37 & 6.72 & 6.94 & 1.67 & 0.84 \\
\hline$C^{*}$ & 16.47 & 15.93 & 17.23 & 2.66 & 0.70 \\
\hline$H^{*}$ & 22.51 & 25.60 & 23.61 & 5.17 & 0.59 \\
\hline $\mathrm{pH}$ & 6.1 & 6.04 & 6.19 & 0.522 & 0.885 \\
\hline Drip loss (\%) & 1.97 & 1.78 & 1.56 & 0.44 & 0.294 \\
\hline Cooking loss (\%) & 0.29 & 0.31 & 0.26 & 0.04 & 0.126 \\
\hline Protein $(\mathrm{g} / 100 \mathrm{~g})$ & 23.84 & 23.59 & 23.91 & 1.11 & 0.875 \\
\hline Fat $(\mathrm{g} / 100 \mathrm{~g})$ & $1.35^{\mathrm{b}}$ & $1.76^{\mathrm{a}}$ & $1.82^{\mathrm{a}}$ & 0.27 & 0.047 \\
\hline
\end{tabular}

SEM, standard error of means. C, control group; FD1, $100 \mathrm{~g}$ microalgae powder per bull per day of basal diet; FD2, $200 \mathrm{~g}$ microalgae powder per bull per day of basal diet. ${ }^{\mathrm{a}, \mathrm{b}}$ Means within a row with different superscripts differ $(p<0.05)$.

\subsection{Fatty Acid Composition}

The influences of dietary DHA-rich microalgae on fatty acids composition in the LL muscle of beef are given in Table 4. It could be seen that dietary DHA-rich microalgae treatments had no effects on monounsaturated fatty acids (MUFA) and n-6 PUFA $(p>0.05)$ Saturated fatty acids (SFA) in the FD1 and FD2 groups was greater $(p<0.05)$ than that in the control group. The cattle supplemented with DHA-rich microalgae had higher SFA $(p=0.007)$, PUFA $(p=0.001)$, n-3 PUFA $(p<0.001)$ and EPA + DHA $(p<0.001)$, and a lower $(p<0.001) \mathrm{n}-6 / \mathrm{n}-3$ ratio. Moreover, the concentrations of EPA, DHA, EPA + DHA and total n-3 PUFA increased significantly with increasing DHA-rich microalgae $(p<0.001)$. The relative proportion of EPA and DHA were 4-6 times and 8.5-11.4 times higher $(p<0.001)$ for FD1 and FD2 groups compared to the control group.

Table 4. The influence of dietary DHA-rich microalgae on fatty acid profiles of beef meat.

\begin{tabular}{|c|c|c|c|c|c|}
\hline \multirow{2}{*}{$\begin{array}{c}\text { Item } \\
\text { (mg/100 g Fresh Meat) }\end{array}$} & \multicolumn{3}{|c|}{ Treatments } & \multirow{2}{*}{ SEM } & \multirow{2}{*}{$p$-Value } \\
\hline & $\mathrm{C}$ & FD1 & FD2 & & \\
\hline C14:0 & 17.64 & 23.00 & 24.99 & 8.11 & 0.297 \\
\hline C15:0 & 6.85 & 7.34 & 8.86 & 1.66 & 0.111 \\
\hline C16:0 & $248.47^{b}$ & $327.77^{a}$ & $336.94^{a}$ & 59.86 & 0.042 \\
\hline C17:0 & 14.39 & 19.11 & 19.06 & 4.64 & 0.164 \\
\hline C18:0 & 236.01 & 331.83 & 357.42 & 86.44 & 0.065 \\
\hline C20:0 & $2.86^{b}$ & $3.35^{a b}$ & $4.41^{\mathrm{a}}$ & 0.97 & 0.041 \\
\hline C21:0 & 1.71 & 1.89 & 1.39 & 0.53 & 0.285 \\
\hline C22:0 & 0.08 & 0.07 & 0.07 & 0.01 & 0.752 \\
\hline C23:0 & 1.01 & 1.11 & 1.16 & 0.19 & 0.386 \\
\hline SFA & $529.03^{b}$ & $715.48^{a}$ & $754.29^{a}$ & 111.74 & 0.007 \\
\hline C15:1 & 82.88 & 90.44 & 86.85 & 17.87 & 0.768 \\
\hline C16:1 & $20.08^{b}$ & $27.86^{a, b}$ & $36.46^{\mathrm{a}}$ & 7.12 & 0.004 \\
\hline C18:1 n-9 & 213.31 & 222.08 & 286.45 & 91.73 & 0.347 \\
\hline C20:1 & 1.88 & 1.90 & 1.98 & 0.64 & 0.962 \\
\hline
\end{tabular}


Table 4. Cont.

\begin{tabular}{|c|c|c|c|c|c|}
\hline \multirow{2}{*}{$\begin{array}{c}\text { Item } \\
\text { (mg/100 g Fresh Meat) }\end{array}$} & \multicolumn{3}{|c|}{ Treatments } & \multirow{2}{*}{ SEM } & \multirow{2}{*}{$p$-Value } \\
\hline & C & FD1 & FD2 & & \\
\hline C22:1 & 1.60 & 1.63 & 2.02 & 0.45 & 0.230 \\
\hline MUFA & 319.75 & 343.92 & 413.76 & 104.80 & 0.301 \\
\hline C18:2 n-6 & 165.56 & 176.09 & 160.43 & 35.64 & 0.744 \\
\hline C18:3 n-6 & 1.29 & 1.54 & 1.20 & 0.28 & 0.128 \\
\hline C18:3 n-3 (ALA) & $5.31^{\mathrm{b}}$ & $6.33^{a}$ & $6.82^{a}$ & 0.74 & 0.009 \\
\hline$C 20: 2 n-6$ & 5.09 & 5.02 & 5.68 & 1.26 & 0.614 \\
\hline C20:3 n-6 & 13.39 & 11.86 & 11.16 & 2.31 & 0.261 \\
\hline C20:4 n-6 & 73.76 & 74.48 & 85.72 & 9.91 & 0.096 \\
\hline C20:5 n-3 (EPA) & $3.46^{\mathrm{c}}$ & $12.34^{\mathrm{b}}$ & $18.87^{\mathrm{a}}$ & 2.44 & $<0.001$ \\
\hline C22:6 n-3 (DHA) & $7.33^{c}$ & $60.30^{b}$ & $80.19^{a}$ & 5.24 & $<0.001$ \\
\hline PUFA & $275.19^{b}$ & $351.51^{a}$ & $370.09^{a}$ & 36.86 & 0.001 \\
\hline n-6 PUFA & 259.10 & 268.98 & 264.20 & 36.54 & 0.897 \\
\hline n-3 PUFA & $16.10^{\mathrm{c}}$ & $78.97^{b}$ & $105.89^{a}$ & 6.19 & $<0.001$ \\
\hline $\mathrm{EPA}+\mathrm{DHA}$ & $10.79^{c}$ & $72.64^{b}$ & $99.06^{\mathrm{a}}$ & 6.28 & $<0.001$ \\
\hline$n-6 / n-3$ & $16.15^{\mathrm{a}}$ & $3.43^{b}$ & $2.52^{b}$ & 1.13 & $<0.001$ \\
\hline
\end{tabular}

SEM, standard error of means; SFA, saturated fatty acids; MUFA, monounsaturated fatty acids; PUFA, polyunsaturated fatty acids; DHA, docosahexaenoic acid; EPA, eicosapentaenoic acid; C, control group; FD1, 100 g microalgae powder per bull per day of basal diet; FD2, $200 \mathrm{~g}$ microalgae powder per bull per day of basal diet. Within a row, values with different superscript letters are significantly different. Different superscripts within a row differ significantly $(p<0.05)$. SFA $=\mathrm{C} 14: 0+\mathrm{C} 15: 0+\mathrm{C} 16: 0+\mathrm{C} 17: 0+\mathrm{C} 18: 0+\mathrm{C} 20: 0+\mathrm{C} 21: 0+\mathrm{C} 22: 0+\mathrm{C} 23: 0$ MUFA $=$ C15:1 + C16:1 + C18:1 n-9 + C20:1 + C22:1. PUFA = C18:2 n-6 + C18:3 n-6 + C20:2 n-6 + C20:3 n-6 + C20:4 n-6 + C18:3 n-3 + C20:5 n-3 + C22:6 n-3. n-6 PUFA = C18:2 n-6 + C18:3 n-6 + C20:2 n-6 + C20:3 n-6 + C20:4 n-6. n-3 PUFA $=$ C18:3 n-3 + C20:5 n-3 + C22:6 n-3.

Diet also influenced individual fatty acid contents, whereas C16:0 and C18:3 n-3 (ALA) in the FD1 and FD2 groups was higher $(p<0.05)$ than that in the control group. DHA-rich microalgae increased the concentrations of C16:0 and SFA in the meat, which may be related to the higher contents of C16:0 and SFA contained in microalgae powder, which were difficult to be oxidized and easy to deposit [15]. The concentrations of C20:0 and C16:1 in the FD2 group were greater $(p<0.05)$ than that in the control group, but there was no difference $(p>0.05)$ from that in the FD1 group.

\subsection{Volatile Compounds}

As shown in Figure 2, the abscissa was used to represent the drift time, and the ordinate was used to represent the retention time. The drift time and retention time were compared to indicate the volatile compounds in the beef sample. Each spot represented a kind of volatile compound. The identified compounds are presented in Table 5. A total of 36 peaks and 24 volatile components were identified from the beef samples of the three groups, including 9 alcohols, 8 aldehydes, 6 ketones and 1 furan. Among them, 11 were dimers of the compounds, and 1 was a trimer of the detected compounds.

Table 5. The information on identified volatile compounds of beef meat (36 peaks for 24 compounds).

\begin{tabular}{|c|c|c|c|c|c|c|c|}
\hline Number & Compound & $\mathrm{CAS}^{\#}$ & Formula & MW & RI & Rt [s] & Dt [ms] \\
\hline 1 & 2-Pentylfuran & C3777693 & $\mathrm{C} 9 \mathrm{H} 14 \mathrm{O}$ & 138.2 & 995.0 & 588.195 & 1.25804 \\
\hline 2 & Benzaldehyde & C100527 & $\mathrm{C} 7 \mathrm{H} 6 \mathrm{O}$ & 106.1 & 958.7 & 511.489 & 1.15827 \\
\hline 3 & n-Nonanal & C124196 & С9H18O & 142.2 & 1103.3 & 790.923 & 1.47531 \\
\hline 4 & Octanal & C124130 & $\mathrm{C} 8 \mathrm{H} 16 \mathrm{O}$ & 128.2 & 1011.5 & 616.193 & 1.40526 \\
\hline 5 & Methional & C3268493 & C4H8OS & 104.2 & 916.8 & 435.272 & 1.08542 \\
\hline 6 & Heptanal (Monomer) & $\mathrm{C} 111717$ & $\mathrm{C} 7 \mathrm{H} 14 \mathrm{O}$ & 114.2 & 900.6 & 409.009 & 1.33262 \\
\hline 7 & Heptanal (Dimer) & C111717 & $\mathrm{C} 7 \mathrm{H} 14 \mathrm{O}$ & 114.2 & 900.0 & 408.054 & 1.7041 \\
\hline 8 & 2-heptanone (Monomer) & C110430 & $\mathrm{C} 7 \mathrm{H} 14 \mathrm{O}$ & 114.2 & 892.3 & 396.116 & 1.26633 \\
\hline 9 & 2-Heptanone (Dimer) & C110430 & $\mathrm{C} 7 \mathrm{H} 14 \mathrm{O}$ & 114.2 & 891.9 & 395.639 & 1.64334 \\
\hline 10 & 1-Hexanol (Monomer) & C111273 & $\mathrm{C} 6 \mathrm{H} 14 \mathrm{O}$ & 102.2 & 871.8 & 368.421 & 1.32986 \\
\hline 11 & 1-Hexanol (Dimer) & C111273 & C6H14O & 102.2 & 872.1 & 368.898 & 1.64472 \\
\hline
\end{tabular}


Table 5. Cont.

\begin{tabular}{|c|c|c|c|c|c|c|c|}
\hline Number & Compound & CAS $^{\#}$ & Formula & MW & RI & Rt $[s]$ & $\mathrm{Dt}$ [ms] \\
\hline 12 & Hexanal (Monomer) & C66251 & $\mathrm{C} 6 \mathrm{H} 12 \mathrm{O}$ & 100.2 & 792.4 & 278.226 & 1.25507 \\
\hline 13 & Hexanal (Dimer) & C66251 & $\mathrm{C} 6 \mathrm{H} 12 \mathrm{O}$ & 100.2 & 791.8 & 277.602 & 1.57443 \\
\hline 14 & 1-Pentanol (Monomer) & C71410 & $\mathrm{C} 5 \mathrm{H} 12 \mathrm{O}$ & 88.1 & 764.5 & 251.354 & 1.24767 \\
\hline 15 & 1-Pentanol (Dimer) & C71410 & $\mathrm{C} 5 \mathrm{H} 12 \mathrm{O}$ & 88.1 & 762.4 & 249.479 & 1.51031 \\
\hline 16 & 2-Hexanone & C591786 & $\mathrm{C} 6 \mathrm{H} 12 \mathrm{O}$ & 100.2 & 783.7 & 269.79 & 1.18602 \\
\hline 17 & Acetoin (Monomer) & C513860 & $\mathrm{C} 4 \mathrm{H} 8 \mathrm{O} 2$ & 88.1 & 716.1 & 210.419 & 1.05532 \\
\hline 18 & Acetoin (Dimer) & C513860 & $\mathrm{C} 4 \mathrm{H} 8 \mathrm{O} 2$ & 88.1 & 713.6 & 208.544 & 1.34015 \\
\hline 19 & 1-Butanol (Monomer) & C71363 & $\mathrm{C} 4 \mathrm{H} 10 \mathrm{O}$ & 74.1 & 663.8 & 177.922 & 1.18356 \\
\hline 20 & 1-Butanol (Dimer) & C71363 & $\mathrm{C} 4 \mathrm{H} 10 \mathrm{O}$ & 74.1 & 659.9 & 176.047 & 1.37591 \\
\hline 21 & 2-Butanone (Monomer) & C78933 & $\mathrm{C} 4 \mathrm{H} 8 \mathrm{O}$ & 72.1 & 581.6 & 142.612 & 1.06395 \\
\hline 22 & 2-Butanone (Dimer) & C78933 & $\mathrm{C} 4 \mathrm{H} 8 \mathrm{O}$ & 72.1 & 588.9 & 145.424 & 1.25137 \\
\hline 23 & 1-Propanol & C71238 & $\mathrm{C} 3 \mathrm{H} 8 \mathrm{O}$ & 60.1 & 560.7 & 134.8 & 1.11204 \\
\hline 24 & Acetone & C67641 & $\mathrm{C} 3 \mathrm{H} 6 \mathrm{O}$ & 58.1 & 489.8 & 111.364 & 1.1256 \\
\hline 25 & 2-Propanol & C67630 & $\mathrm{C} 3 \mathrm{H} 8 \mathrm{O}$ & 60.1 & 501.1 & 114.802 & 1.18232 \\
\hline 26 & Ethanol & C64175 & $\mathrm{C} 2 \mathrm{H} 6 \mathrm{O}$ & 46.1 & 458.3 & 102.303 & 1.04546 \\
\hline 27 & 2-Methylpropanol & C78831 & $\mathrm{C} 4 \mathrm{H} 10 \mathrm{O}$ & 74.1 & 620.3 & 158.236 & 1.17492 \\
\hline 28 & 2-Pentanone (Monomer) & C107879 & $\mathrm{C} 5 \mathrm{H} 10 \mathrm{O}$ & 86.1 & 685.3 & 188.546 & 1.12067 \\
\hline 29 & 2-Pentanone (Dimer) & C107879 & $\mathrm{C} 5 \mathrm{H} 10 \mathrm{O}$ & 86.1 & 685.8 & 188.78 & 1.37521 \\
\hline 30 & 3-Methylbutanal & C590863 & $\mathrm{C} 5 \mathrm{H} 10 \mathrm{O}$ & 86.1 & 652.1 & 172.421 & 1.40027 \\
\hline 31 & 1-Octen-3-ol (Monomer) & C3391864 & $\mathrm{C} 8 \mathrm{H} 16 \mathrm{O}$ & 128.2 & 985.9 & 567.857 & 1.16379 \\
\hline 32 & 1-Octen-3-ol (Dimer) & C3391864 & $\mathrm{C} 8 \mathrm{H} 16 \mathrm{O}$ & 128.2 & 984.8 & 565.584 & 1.61059 \\
\hline 33 & 1-Octen-3-ol (Trimer) & C3391864 & $\mathrm{C} 8 \mathrm{H} 16 \mathrm{O}$ & 128.2 & 987.3 & 571.04 & 1.73824 \\
\hline 34 & Pentanal (Monomer) & C110623 & $\mathrm{C} 5 \mathrm{H} 10 \mathrm{O}$ & 86.1 & 695.9 & 195.421 & 1.18443 \\
\hline 35 & Pentanal (Dimer) & C110623 & $\mathrm{C} 5 \mathrm{H} 10 \mathrm{O}$ & 86.1 & 694.3 & 194.228 & 1.42808 \\
\hline 36 & 2-Ethylhexanol & C104767 & $\mathrm{C} 8 \mathrm{H} 18 \mathrm{O}$ & 130.2 & 1043.5 & 672.122 & 1.40894 \\
\hline
\end{tabular}

$\mathrm{CAS}^{\#}$, the registration number of chemical substances; MW, molecular mass; RI, retention index; Rt, retention; Dt, drift time.

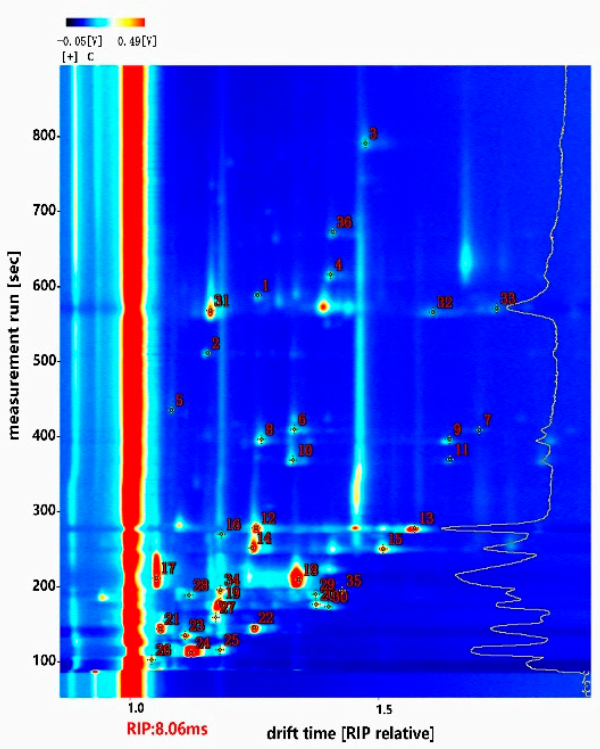

(A)

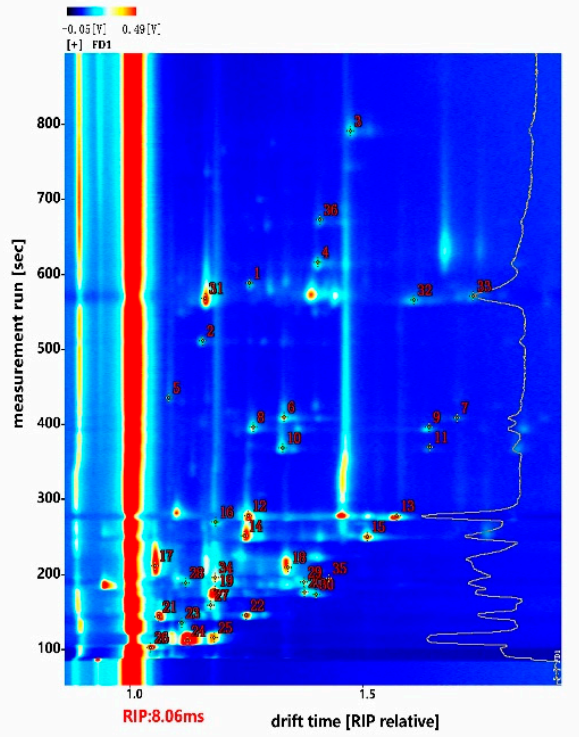

(B)

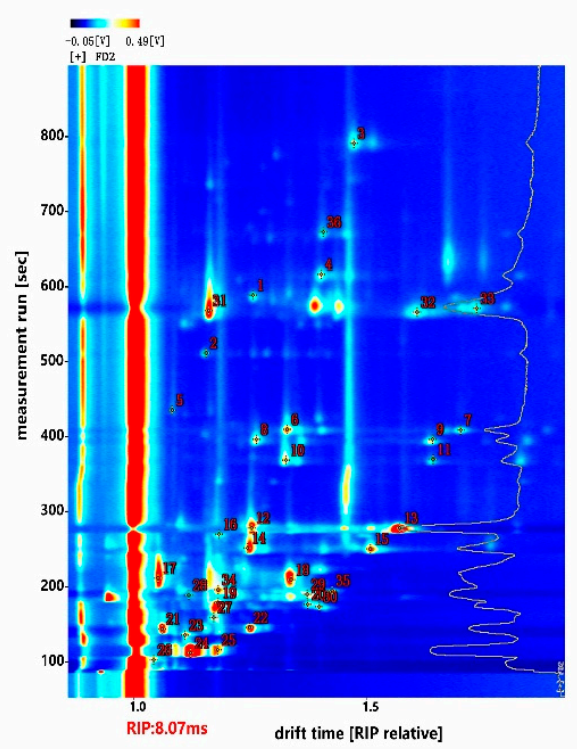

(C)

Figure 2. Ion migration spectra of beef meat under different treatments. RIP, reactive ion peak. (A) C, control group; (B) FD1, $100 \mathrm{~g}$ microalgae powder per bull per day of basal diet; (C) FD2, $200 \mathrm{~g}$ microalgae powder per bull per day of basal diet.

To further study the flavor difference between beef samples after adding microalgae, the fingerprints obtained are shown in Figure 3. The fingerprint was formed based on the peak signal. Each row represented the sample, and each column represented the identified volatile compounds. In the fingerprint, the more pronounced color indicated, the higher the content of the flavor substance identified. The contents of 2-propanol and acetone in the 
FD1 and FD2 groups were much higher than that in the control group. In the FD2 group, it was found that the concentrations of many compounds in beef greatly increased, such as 1-hexanol, 1-octen-3-ol, 2-ethylhexanol, n-nonanal, octanal, heptanal, hexanal (dimer), pentanal (dimer), 2-heptanone and 2-pentylfuran. However, the concentrations of acetoin, 2-pentanone (monomer) and 2-butanone (monomer) were the highest in the control group.

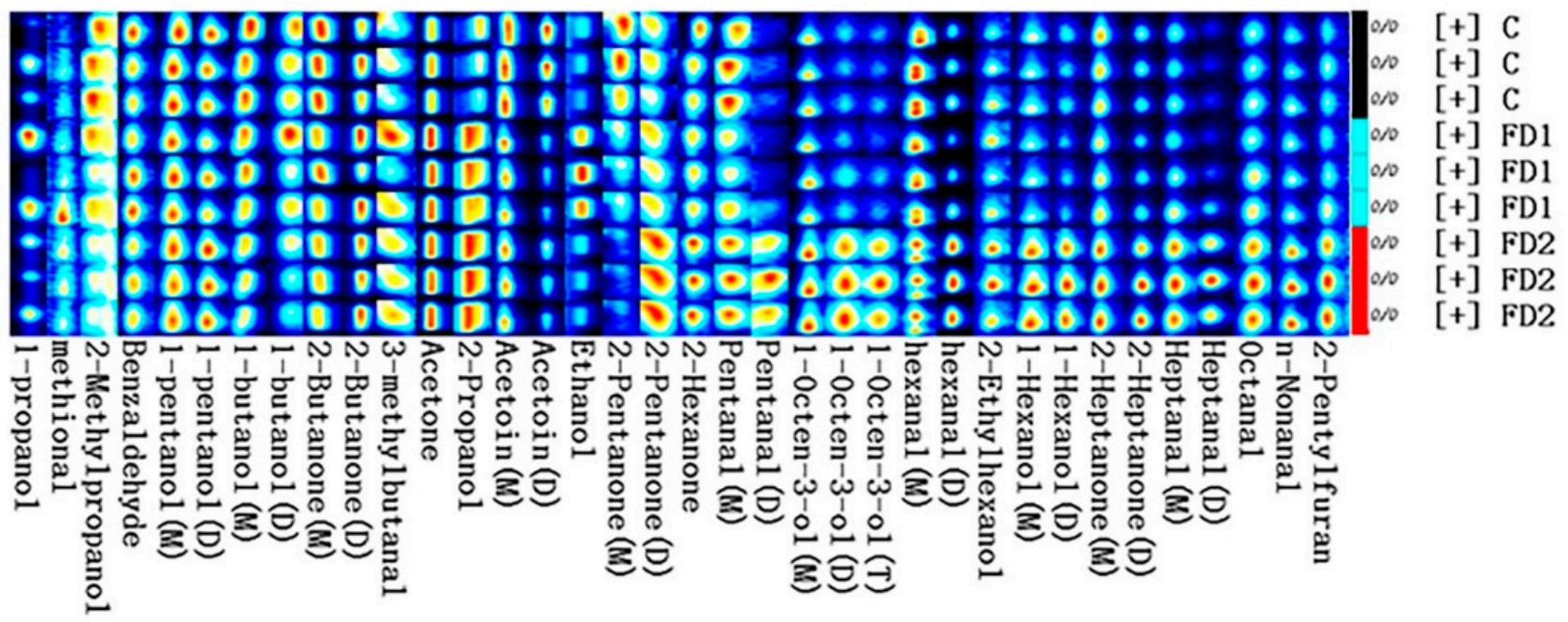

Figure 3. Gallery plots of volatile compounds of beef treated with different levels of DHA-rich microalgae. All signal strengths are expressed in color. The redder the spot indicates the greater the amount of volatile compounds detected. C, control group; FD1, $100 \mathrm{~g}$ microalgae powder per bull per day of basal diet; FD2, $200 \mathrm{~g}$ microalgae powder per bull per day of basal diet.

\subsection{Sensory Evaluation}

The mean scores for sensory evaluation of beef are presented in Table 6. Compared with the beef samples of the control group, the beef samples of the FD1 and FD2 groups showed higher $(p<0.05)$ scores of initial juiciness, sustained juiciness, flavor intensity, initial tenderness and sustained tenderness, and lower $(p<0.05)$ scores of residue. There was no observed effect of diet (FD1 or FD2) on off-flavor intensity $(p>0.05)$. However, the sensory scores between the FD1 and FD2 groups did not show a significant difference $(p>0.05)$.

Table 6. Effect of dietary DHA-rich microalgae on sensory characteristics of beef.

\begin{tabular}{cccccc}
\hline \multirow{2}{*}{ Item } & \multicolumn{3}{c}{ Treatments } & \multirow{2}{*}{ SEM } & $p$-Value \\
\cline { 2 - 4 } & $\mathbf{C}$ & FD1 & FD2 & & 0.006 \\
\hline Initial juiciness & $5.13^{\mathrm{b}}$ & $6.19^{\mathrm{a}}$ & $6.21^{\mathrm{a}}$ & 0.56 & 0.012 \\
Sustained juiciness & $4.94^{\mathrm{b}}$ & $5.94^{\mathrm{a}}$ & $6.10^{\mathrm{a}}$ & 0.63 & 0.004 \\
Flavor intensity & $5.48^{\mathrm{b}}$ & $6.33^{\mathrm{a}}$ & $6.44^{\mathrm{a}}$ & 0.45 & 0.187 \\
Off-flavor intensity & $2.17^{\mathrm{b}}$ & $2.00^{\mathrm{a}}$ & $2.31^{\mathrm{a}}$ & 0.28 & 0.029 \\
Initial tenderness & $5.52^{\mathrm{b}}$ & $6.33^{\mathrm{a}}$ & $6.50^{\mathrm{a}}$ & 0.60 & 0.049 \\
Sustained tenderness & $5.63^{\mathrm{b}}$ & $6.35^{\mathrm{a}}$ & $6.42^{\mathrm{a}}$ & 0.56 & 0.022 \\
Residue & $3.68^{\mathrm{a}}$ & $3.21^{\mathrm{b}}$ & $3.10^{\mathrm{b}}$ & 0.34 & \\
\hline
\end{tabular}

SEM, standard error of means. C, control group; FD1, $100 \mathrm{~g}$ microalgae powder per bull per day of basal diet; FD2, $200 \mathrm{~g}$ microalgae powder per bull per day of basal diet. ${ }^{\mathrm{a}, \mathrm{b}}$ Means within a row with different superscripts differ $(p<0.05)$.

\section{Discussion}

It is known that antioxidant capacity is an important factor in maintaining animal health [32]. As a part of the endogenous antioxidant defense system, antioxidant enzymes played a key role, which could protect cells from oxidative damage by free radicals [33]. 
A previous study showed that Schizochytrium contained some antioxidants such as $\beta$ carotene and vitamin E [15]. SOD directly reacts with free radicals to remove hydrogen peroxide [34], while GSH-Px catalyzes the decomposition of hydrogen peroxide [35]. In this study, compared with the control group, the addition of DHA-rich microalgae increased the T-AOC of beef meat, which indicated that DHA-rich microalgae could improve the antioxidant status of beef. It was found that only the GSH-Px activity in the FD1 group increased in the current study, which suggested that the antioxidants in the microalgae at an appropriate dose might contribute to the stability of the meat after slaughter. Adding DHA-rich microalgae to the diet did not affect the SOD activity of beef. This finding is consistent with La et al. [36], who reported that supplementing the diet with Schizochytrium did not affect the SOD activity in the blood of calves. The content of TBARS is considered to be one of the most accurate indicators for evaluating lipid peroxidation [37]. Since long-chain PUFA was the main target of reactive oxygen species, it was determined that the risk of lipid oxidation of beef was increased [38]. Our results showed that the addition of DHA-rich microalgae in the diet did not affect TBARS. This result could be explained that the increase in antioxidant capacity and endogenous antioxidant enzyme activity (GSH-Px) scavenged free radicals to protect PUFA, resulting in no lipid peroxidation, although the concentration of PUFA of beef meat increased after adding microalgae to the diet.

Meat color is an important indicator for evaluating meat quality, which determines the consumers' desire to buy [39]. In the present research, no changes in beef meat color between groups were observed, which is consistent with previous studies. They reported that adding DHA-rich Schizochytrium did not affect the animal meat color [40-42]. The lack of differences in the ultimate $\mathrm{pH}$ between the treatments indicates that the muscle glycogen levels of the beef in the three treatment groups are similar. Drip loss and cooking loss were used to evaluate the water holding capacity of the meat. It should be noted that no difference in water retention was observed between the three treatments. The amount of intramuscular fat is related to eating qualities such as juiciness, tenderness and flavor [43]. Urrutia et al. [44] reported that dietary microalgae changed adipose tissue development and cell structure, which may be an important factor in causing fat deposition in this study. Generally, the strategy of using microalgae as a diet does not affect meat quality parameters [45], but it could improve the fatty acid composition of the meat. This deserves more attention and further research.

With the increase of DHA-rich microalgae supplemented in the diet, the contents of EPA, DHA, EPA + DHA and n-3 PUFA showed a linear increase. As expected, marine resources exhibited the ability to accumulate DHA and EPA contents in meat [46]. There was evidence that adding algae to the diet was easier to obtain DHA deposition than through the desaturation and prolongation pathway of $\alpha$-Linolenic acid (C18:3 n-3, ALA) [47]. Based on the Australian nutrient reference standard, if the EPA + DHA in red meat exceeds $60 \mathrm{mg} / 135 \mathrm{~g}$ meat, it could be considered as a good source of n-3 [44]. The European standard for a good source of $\mathrm{n}-3$ recognized EPA + DHA as $40 \mathrm{mg}$ and $80 \mathrm{mg} / 100 \mathrm{~g}$ of meat [48]. In this experiment, the content of EPA + DHA in beef $(60.30 \mathrm{mg} / 100 \mathrm{~g}$ fresh meat and $80.19 \mathrm{mg} / 100 \mathrm{~g}$ fresh meat) was sufficient to meet this standard, which meant that the beef in this study could provide enough EPA and DHA for the healthy human diet. The balance of the ratio of $n-6$ and n-3 PUFA is a key factor for maintaining human health [49]. Burghardt et al. reported that the n-6/n-3 PUFA ratio in the human diet should not exceed 4 [50]. In this study, the ideal ratio of $n-6 / n-3$ in beef meat in the FD1 and FD2 groups illustrated that this beef meat could help reduce the risk of cardiovascular and cerebrovascular diseases and certain cancers after being consumed by humans [51]. The changes in fatty acid composition observed in this study may be attributed to the differences in fatty acid metabolism and deposition of beef with different dietary treatments [52]. In addition, in the absence of $\mathrm{C} 18: 3 \mathrm{n}-6$ in the diet, the C18:3 n- 6 detected in beef meat may be attributed to the conversion of C18:2 n- 6 through elongation and desaturation from certain diets in this experiment [53]. 
Volatile alcohols, aldehydes and ketones belong to lipid-derived compounds [54]. They are the simplest product of lipid degradation and are formed by the modification of fatty acids after removal from the glycerol backbone [55]. In this experiment, short-chain fatty aldehydes content was found to be the highest in the FD2 group, such as n-nonanal, octanal, heptanal, hexanal and pentanal, and hexanal was the highest amount of them. Most aldehydes are mainly derived from oleic acid (C18:1 n-9) and linoleic acid (C18:2 n-6), but nonanal was only produced from oleic acid [56]. The results clearly illustrate that the high correlation between the flavor compound and fatty acid composition, and the decisive role of lipids in the formation of basic meat flavor. Previous studies showed that aldehydes were the main volatile compounds in beef meat $[57,58]$. Volatile compounds were mainly affected by diet because the fatty acid composition of meat was changed by diet [59]. Therefore, this also explained the higher aldehyde content in the FD2 group. Hexanal was the main volatile compound in beef meat and directly related to lipid auto-oxidation [60]. The alcohols observed in the experiment were secondary products of aldehydes. The FD1 group showed a higher amount of ethanol. It is interesting that due to the higher alcohol threshold, the contribution to the undesirable flavor of the meat was less [61]. However, the highest content of 1-octen-3-ol in the FD2 group could indicate a mushroom flavor, which could be perceived as a mushroom-related flavor. The highest value of 2-pentylfuran (beany and grassy flavor) was observed in the FD2 group, which could be formed by lipid oxidation and degradation. It was an oxygen-containing heterocyclic compound with a low threshold, resulting in a greater contribution to the overall flavor of the meat [62]. Prior work has shown that ketones were derived from the $\beta$-oxidation of free fatty acids increased with fat content in meat [63]. Acetoin (buttery flavor), 2-butanone and 2-pentanone levels in the $C$ group were significantly higher than the other two groups, suggesting that the fat content was reduced by DHA-rich microalgae. To our knowledge, there is no information on the effect of an algae diet on volatile beef compounds. In the current study, high levels of volatile compounds were associated with high levels of DHA in the meat of algae-fed animals.

Most consumers believe that higher fat is related to greater eating satisfaction [64]. This study found that consumers' liking of tenderness, juiciness and flavor were affected by diet. The aldehydes produced by the Strecker degradation of the Maillard reaction were generally considered to be positive flavors associated with cooking [65]. This is consistent with the results of volatile substances in this study. There was no difference in the off-flavor scores of the three groups, which might be related to the TBARS value in the meat (less than $0.5 \mathrm{mg} \mathrm{MDA} / \mathrm{kg}$ meat) [66]. This study proved that adding DHA-rich microalgae to the diet could reduce the development of off-flavor by increasing oxidative stability.

\section{Conclusions}

In conclusion, adding different levels of DHA-rich microalgae to the diet could increase the activity of certain antioxidant enzymes in beef. Our results demonstrate that DHA and EPA levels in meat were enriched by supplementing DHA-rich microalgae. In addition, the reduced ratio of n-6/n-3 was another potential health benefit associated with algae in Schizochytrium sp. At the same time, the supplementation of DHA-rich microalgae enhanced the volatile compounds in beef, especially in the high-dose FD2 group. It is necessary to conduct further research on the metabolites and oxidation mechanism of fatty acids in meat.

Author Contributions: Conceptualization, C.X. and B.S.; methodology, C.X. and F.L.; software, C.X.; validation, S.Z. (Shou Zhang), S.Z. (Songshan Zhang) and L.C.; formal analysis, X.L.; investigation, B.S.; resources, P.X.; data curation, C.X.; writing—original draft preparation, C.X.; writing - review and editing, S.Z. (Songshan Zhang); visualization, S.Z. (Songshan Zhang); supervision, S.Z. (Shou Zhang); project administration, S.Z. (Songshan Zhang) and S.Z. (Shou Zhang); funding acquisition, S.Z. (Shou Zhang). All authors have read and agreed to the published version of the manuscript. 
Funding: This research was supported by the Special Basic Research Fund for Central Public Research Institutes (No. 2021-YWF-ZYSQ-07), the Science and Technology research project of Hebei Education Department (BJ2018061), the Program of National Beef Cattle and Yak Industrial Technology System (CARS-37) and the Improvement of Qaidam Beef Meat Quality and the Development and Promotion of Beef Products (2020-QY-217).

Institutional Review Board Statement: All procedures were approved by the Experimental Animal Welfare and Ethical Committee, Institute of Animal Science, Chinese Academy of Agricultural Sciences (IAS2017-2).

Data Availability Statement: Data are available from the corresponding author upon request.

Acknowledgments: The authors would like to thank Hui Li and Ri Hu for their technical support.

Conflicts of Interest: The authors declare no conflict of interest.

\section{References}

1. Li, X.Z.; Yan, C.G.; Zan, L.S. Current situation and future prospects for beef production in China-A review. Asian-Australas J. Anim. Sci. 2018, 31, 984-991. [CrossRef]

2. Toral, P.G.; Hervás, G.; Carreño, D.; Leskinen, H.; Belenguer, A.; Shingfield, K.J.; Frutos, P. In vitro response to EPA, DPA, and DHA: Comparison of effects on ruminal fermentation and biohydrogenation of 18-carbon fatty acids in cows and ewes. J. Dairy Sci. 2017, 100, 6187-6198. [CrossRef]

3. Tocher, D.R.; Betancor, M.B.; Sprague, M.; Olsen, R.E.; Napier, J.A. Omega-3 long-chain polyunsaturated fatty acids, EPA and DHA: Bridging the gap between supply and demand. Nutrients 2019, 11, 89. [CrossRef]

4. Colussi, G.; Catena, C.; Novello, M.; Bertin, N.; Sechi, L.A. Impact of omega-3 polyunsaturated fatty acids on vascular function and blood pressure: Relevance for cardiovascular outcomes. Nutr. Metab. Cardiovasc. Dis. 2017, 27, 191-200. [CrossRef]

5. Kalogeropoulos, N.; Chiou, A.; Gavala, E.; Christea, M.; Andrikopoulos, N.K. Nutritional evaluation and bioactive microconstituents (carotenoids, tocopherols, sterols and squalene) of raw and roasted chicken fed on DHA-rich microalgae. Food Res. Int. 2010, 43, 2006-2013. [CrossRef]

6. Lagarde, M. Docosahexaenoic acid: Nutrient and precursor of bioactive lipids. Eur. J. Lipid. Sci. Technol. 2008, 110, 673-678. [CrossRef]

7. Plourde, M.; Cunnane, S.C. Extremely limited synthesis of long chain polyunsaturates in adults: Implications for their dietary essentiality and use as supplements. Appl. Physiol. Nutr. Metab. 2007, 32, 619-634. [CrossRef]

8. Bryhni, E.A.; Kjos, N.P.; Ofstad, R.; Hunt, M. Polyunsaturated fat and fish oil in diets for growing-finishing pigs: Effects on fatty acid composition and meat, fat, and sausage quality. Meat Sci. 2002, 62,1-8. [CrossRef]

9. Kahraman, R.; Özpınar, H.; Abas, İ.; Kutay, H.C.; Eseceli, H.; Grashorn, M. Effects of different dietary oil sources on fatty acid composition and malondialdehyde levels of thigh meat in broiler chickens. Arch. Geflugelkd. 2004, 68, 77-86.

10. Wood, J.D.; Enser, M.; Fisher, A.V.; Nute, G.R.; Sheard, P.R.; Richardson, R.I.; Hughes, S.I.; Whittington, F.M. Fat deposition, fatty acid composition and meat quality: A review. Meat Sci. 2008, 78, 343-358. [CrossRef] [PubMed]

11. Madeira, M.S.; Cardoso, C.; Lopes, P.A.; Coelho, D.; Afonso, C.; Bandarra, N.M.; Prates, J.A. Microalgae as feed ingredients for livestock production and meat quality: A review. Livest. Sci. 2017, 205, 111-121. [CrossRef]

12. Altomonte, I.; Salari, F.; Licitra, R.; Martini, M. Use of microalgae in ruminant nutrition and implications on milk quality-A review. Livest. Sci. 2018, 214, 25-35. [CrossRef]

13. Mastellone, V.; Morittu, V.M.; Musco, N.; Spina, A.A.; Malgeri, A.; Molinari, M.L.; D’Aniello, B.; Infascelli, F.; Tudisco, R.; Lombardi, P. Dietary supplementation with a phytocomplex affects blood parameters and milk yield and quality in grazing goats. Small Ruminant Res. 2021, 201, 106421. [CrossRef]

14. Caporgno, M.P.; Mathys, A. Trends in microalgae incorporation into innovative food products with potential health benefits. Front. Nutr. 2018, 5, 58. [CrossRef]

15. Long, S.F.; Kang, S.; Wang, Q.Q.; Xu, Y.T.; Pan, L.; Hu, J.X.; Li, M.; Piao, X.S. Dietary supplementation with DHA-rich microalgae improves performance, serum composition, carcass trait, antioxidant status, and fatty acid profile of broilers. Poult. Sci. 2018, 97, 1881-1890. [CrossRef] [PubMed]

16. Abdelnour, S.A.; Sheiha, A.M.; Taha, A.E.; Swelum, A.A.; Alarifi, S.; Alkahtani, S.; Ali, D.; AlBasher, G.; Almeer, R.; Falodah, F.; et al. Impacts of enriching growing rabbit diets with chlorella vulgaris microalgae on growth, blood variables, carcass traits, immunological and antioxidant indices. Animals 2019, 9, 788. [CrossRef]

17. El-Bahr, S.; Shousha, S.; Shehab, A.; Khattab, W.; Ahmed-Farid, O.; Sabike, I.; El-Garhy, O.; Albokhadaim, I.; Albosadah, K. Effect of dietary microalgae on growth performance, profiles of amino and fatty acids, antioxidant status, and meat quality of broiler chickens. Animals 2020, 10, 761. [CrossRef]

18. Holman, B.W.B.; Malau-Aduli, A.E.O. Spirulina as a livestock supplement and animal feed. J. Anim. Physiol. Anim. Nutr. 2013, 97, 615-623. [CrossRef]

19. Abril, R.; Garrett, J.; Zeller, S.G.; Sander, W.J.; Mast, R.W. Safety assessment of DHA-rich microalgae from Schizochytrium sp. Part V: Target animal safety/toxicity study in growing swine. Regul. Toxicol. Pharmacol. 2003, 37, 73-82. [CrossRef] 
20. Li, M.H.; Robinson, E.H.; Tucker, C.S.; Manning, B.B.; Khoo, L. Effects of dried algae Schizochytrium sp., a rich source of docosahexaenoic acid, on growth, fatty acid composition, and sensory quality of channel catfish Ictalurus punctatus. Aquaculture 2009, 292, 232-236. [CrossRef]

21. Demeda, M.A.; Tomaluski, C.R.; Baggio, C.; Mateus, K.A.; Petrolli, T.G.; Mueller, L.F.; Pereira, A.S.C.; Griebler, L.; Zotti, C.A. Feeding microalgae (Schizochytrium limacinum) to beef steers increases meat omega-3 content. Res. Soc. Dev. 2020, 9, e675974568. [CrossRef]

22. de Lima Valença, R.; da Silva Sobrinho, A.G.; Borghi, T.H.; Meza, D.A.R.; de Andrade, N.; Silva, L.G.; Bezerra, L.R. Performance, carcass traits, physicochemical properties and fatty acids composition of lamb's meat fed diets with marine microalgae meal (Schizochytrium sp.). Livest. Sci. 2021, 243, 104387. [CrossRef]

23. Do Nascimento, T.C.; Cazarin, C.B.; Marostica, M.R., Jr.; Risso, É.M.; Amaya-Farfan, J.; Grimaldi, R.; Mercadante, A.Z.; Jacob-Lopes, E.; Zepka, L.Q. Microalgae biomass intake positively modulates serum lipid profile and antioxidant status. J. Funct. Foods 2019, 58, 11-20. [CrossRef]

24. AOAC. Official Methods of Analysis, 18th ed.; Association of Official Analytical Chemists: Gaithersburg, MD, USA, 2005 ; pp. 12-13.

25. Van Soest, P.V.; Robertson, J.B.; Lewis, B. Methods for dietary fiber, neutral detergent fiber, and nonstarch polysaccharides in relation to animal nutrition. J. Dairy Sci. 1991, 74, 3583-3597. [CrossRef]

26. Li, S.; Ji, H.; Zhang, B.; Tian, J.; Zhou, J.; Yu, H. Influence of black soldier fly (Hermetia illucens) larvae oil on growth performance, body composition, tissue fatty acid composition and lipid deposition in juvenile Jian carp (Cyprinus carpio var. Jian). Aquaculture 2016, 465, 43-52. [CrossRef]

27. Honikel, K.O. Reference methods for the assessment of physical characteristics of meat. Meat Sci. 1998, 49, 447-457. [CrossRef]

28. Fabre, R.; Dalzotto, G.; Perlo, F.; Bonato, P.; Teira, G.; Tisocco, O. Cooking method effect on Warner-Bratzler shear force of different beef muscles. Meat Sci. 2018, 138, 10-14. [CrossRef]

29. Ponnampalam, E.N.; Butler, K.L.; Pearce, K.M.; Mortimer, S.I.; Pethick, D.W.; Ball, A.J.; Hopkins, D.L. Sources of variation of health claimable long chain omega-3 fatty acids in meat from Australian lamb slaughtered at similar weights. Meat Sci. 2014, 96, 1095-1103. [CrossRef]

30. Aldai, N.; Lavín, P.; Kramer, J.K.; Jaroso, R.; Mantecón, A.R. Breed effect on quality veal production in mountain areas: Emphasis on meat fatty acid composition. Meat Sci. 2012, 92, 687-696. [CrossRef]

31. Xu, C.C.; Yu, H.; Xie, P.; Sun, B.Z.; Wang, X.Y.; Zhang, S.S. Influence of electrostatic field on the quality attributes and volatile flavor compounds of dry-cured beef during chill storage. Foods 2020, 9, 478. [CrossRef] [PubMed]

32. Lee, M.T.; Lin, W.C.; Yu, B.; Lee, T.T. Antioxidant capacity of phytochemicals and their potential effects on oxidative status in animals-A review. Asian-Australas J. Anim. Sci. 2017, 30, 299. [CrossRef]

33. Ighodaro, O.M.; Akinloye, O.A. First line defence antioxidants-superoxide dismutase (SOD), catalase (CAT) and glutathione peroxidase (GPX): Their fundamental role in the entire antioxidant defence grid. J. Clin. Investig. 2018, 54, 287-293. [CrossRef]

34. Delles, R.M.; Xiong, Y.L.; True, A.D.; Ao, T.; Dawson, K.A. Dietary antioxidant supplementation enhances lipid and protein oxidative stability of chicken broiler meat through promotion of antioxidant enzyme activity. Poult Sci. 2014, 93, 1561-1570. [CrossRef]

35. Mirzaie, S.; Zirak-Khattab, F.; Hosseini, S.A.; Donyaei-Darian, H. Effects of dietary Spirulina on antioxidant status, lipid profile, immune response and performance characteristics of broiler chickens reared under high ambient temperature. Asian-Australas $J$. Anim. Sci. 2018, 31, 556. [CrossRef] [PubMed]

36. La, A.L.T.Z.; Pierce, K.M.; Liu, W.H.; Gao, S.T.; Bu, D.P.; Ma, L. Supplementation with Schizochytrium sp. enhances growth performance and antioxidant capability of dairy calves before weaning. Anim. Feed Sci. Technol. 2021, $271,114779$.

37. Wang, B.; Xu, C.; Liu, C.; Qu, Y.; Zhang, H.; Luo, H. The effect of dietary lycopene supplementation on drip loss during storage of lamb meat by iTRAQ analysis. Antioxidants 2021, 10, 198. [CrossRef] [PubMed]

38. Xiao, F.; Xing, J.; Li, H.; Xu, X.; Hu, Z.; Ji, H. Effects of the defatted Schizochytrium sp. on growth performance, fatty acid composition, histomorphology and antioxidant status of juvenile mirror carp (Cyprinus carpio var. specularis). Aquac. Res. 2021, 3 , 3062-3076. [CrossRef]

39. Zhang, Y.; Holman, B.W.; Mao, Y.; Chen, X.; Luo, X.; Hopkins, D.L.; Zhang, Y. Determination of a pH threshold for dark cutting beef based on visual evaluation by Asian consumers. Meat Sci. 2021, 172, 108347. [CrossRef]

40. Ribeiro, T.; Lordelo, M.M.; Alves, S.P.; Bessa, R.J.B.; Costa, P.; Lemos, J.P.C.; Ferreira, L.M.A.; Fontes, C.M.G.A.; Prates, J.A.M. Direct supplementation of diet is the most efficient way of enriching broiler meat with $\mathrm{n}$-3 long-chain polyunsaturated fatty acids. Br. Poult. Sci. 2013, 54, 753-765. [CrossRef]

41. Hopkins, D.L.; Clayton, E.H.; Lamb, T.A.; Van de Ven, R.J.; Refshauge, G.; Kerr, M.J.; Bailes, K.; Lewandowski, P.; Ponnampalam, E.N. The impact of supplementing lambs with algae on growth, meat traits and oxidative status. Meat Sci. 2014, 98, 135-141. [CrossRef]

42. Sardi, L.; Martelli, G.; Lambertini, L.; Parisini, P.; Mordenti, A. Effects of a dietary supplement of DHA-rich marine algae on Italian heavy pig production parameters. Livest. Sci. 2006, 103, 95-103. [CrossRef]

43. Pannier, L.; Gardner, G.E.; Pearce, K.L.; McDonagh, M.; Ball, A.J.; Jacob, R.H.; Pethick, D.W. Associations of sire estimated breeding values and objective meat quality measurements with sensory scores in Australian lamb. Meat Sci. 2014, 96, 1076-1087. [CrossRef] [PubMed] 
44. Urrutia, O.; Mendizabal, J.A.; Insausti, K.; Soret, B.; Purroy, A.; Arana, A. Effects of addition of linseed and marine algae to the diet on adipose tissue development, fatty acid profile, lipogenic gene expression, and meat quality in lambs. PLoS ONE 2016, 11, e0156765. [CrossRef]

45. Kalbe, C.; Priepke, A.; Nürnberg, G.; Dannenberger, D. Effects of long-term microalgae supplementation on muscle microstructure, meat quality and fatty acid composition in growing pigs. J. Anim. Phys. Anim. Nutri. 2019, 103, 574-582. [CrossRef] [PubMed]

46. Givens, D.I.; Kliem, K.E.; Gibbs, R.A. The role of meat as a source of $\mathrm{n}-3$ polyunsaturated fatty acids in the human diet. Meat Sci. 2006, 74, 209-218. [CrossRef]

47. Nutrition Information Requirements. Available online: http://www.foodstandards.gov.au/foodstandards/userguides/ nutritioninformation1406.cfm (accessed on 20 July 2016).

48. Commission Regulation of European Union. Amending Regulation (EC) No 1924/2006 of the European Parliament and of the Council with regard to the list of nutrition claims. Off. J. Eur. Union. 2010, 37, 16-18.

49. Calder, P.C. Very long-chain n-3 fatty acids and human health: Fact, fiction and the future. Proc. Nutr. Soc. 2018, 77, 52-72. [CrossRef]

50. Burghardt, P.R.; Kemmerer, E.S.; Buck, B.J.; Osetek, A.J.; Yan, C.; Koch, L.G.; Britton, S.L.; Evans, S.J. Dietary n-3: n-6 fatty acid ratios differentially influence hormonal signature in a rodent model of metabolic syndrome relative to healthy controls. Nutr. Metab. 2010, 7, 1-6. [CrossRef] [PubMed]

51. Jiang, Z.Y.; Xu, C.Y.; Chang, X.X.; Li, W.W.; Sun, L.Y.; Yang, X.B.; Yu, L.F. Fatty liver index correlates with non-alcoholic fatty liver disease, but not with newly diagnosed coronary artery atherosclerotic disease in Chinese patients. BMC Gastroenterol. 2013, 13, 1-6. [CrossRef]

52. Kumar, F.; Tyagi, P.K.; Mir, N.A.; Dev, K.; Begum, J.; Biswas, A.; Sheikh, H.; Tyagi, P.; Sharma, D.; Sahu, B.; et al. Dietary flaxseed and turmeric is a novel strategy to enrich chicken meat with long chain $\omega$-3 polyunsaturated fatty acids with better oxidative stability and functional properties. Food Chem. 2020, 305, 125458. [CrossRef]

53. Rymer, C.; Gibbs, R.A.; Givens, D.I. Comparison of algal and fish sources on the oxidative stability of poultry meat and its enrichment with omega-3 polyunsaturated fatty acids. Poult. Sci. 2010, 89, 150-159. [CrossRef]

54. Zhao, J.; Wang, M.; Xie, J.; Zhao, M.; Hou, L.; Liang, J.; Wang, S.; Cheng, J. Volatile flavor constituents in the pork broth of black-pig. Food Chem. 2017, 226, 51-60. [CrossRef]

55. Kerth, C.R.; Miller, R.K. Beef flavor: A review from chemistry to consumer. J. Sci. Food Agric. 2015, 95, 2783-2798. [CrossRef] [PubMed]

56. Jiang, T.; Busboom, J.R.; Nelson, M.L.; Mengarelli, R. Omega-3 fatty acids affected human perception of ground beef negatively. Meat Sci. 2011, 89, 390-399. [CrossRef]

57. Piao, M.Y.; Yong, H.I.; Lee, H.J.; Fassah, D.M.; Kim, H.J.; Jo, C.; Baik, M. Comparison of fatty acid profiles and volatile compounds among quality grades and their association with carcass characteristics in longissimus dorsi and semimembranosus muscles of Korean cattle steer. Livest. Sci. 2017, 198, 147-156. [CrossRef]

58. Utama, D.T.; Lee, C.W.; Park, Y.S.; Jang, A.; Lee, S.K. Comparison of meat quality, fatty acid composition and aroma volatiles of Chikso and Hanwoo beef. Asian-Australas J. Anim. Sci. 2018, 31, 1500. [CrossRef] [PubMed]

59. Vasta, V.; Priolo, A. Ruminant fat volatiles as affected by diet. A review. Meat Sci. 2006, 73, 218-228. [CrossRef]

60. Morán, L.; Giráldez, F.J.; Panseri, S.; Aldai, N.; Jordán, M.J.; Chiesa, L.M.; Andrés, S. Effect of dietary carnosic acid on the fatty acid profile and flavour stability of meat from fattening lambs. Food Chem. 2013, 138, 2407-2414. [CrossRef]

61. Brewer, M.S. Irradiation effects on meat flavor: A review. Meat Sci. 2009, 81, 1-14. [CrossRef]

62. Song, S.; Tang, Q.; Fan, L.; Xu, X.; Song, Z.; Hayat, K.; Feng, T.; Wang, Y. Identification of pork flavour precursors from enzymetreated lard using Maillard model system assessed by GC-MS and partial least squares regression. Meat Sci. 2017, 124, 15-24. [CrossRef]

63. Legako, J.F.; Dinh, T.T.N.; Miller, M.F.; Adhikari, K.; Brooks, J.C. Consumer palatability scores, sensory descriptive attributes, and volatile compounds of grilled beef steaks from three USDA Quality Grades. Meat Sci. 2016, 112, 77-85. [CrossRef] [PubMed]

64. Lee, Y.; Lee, B.; Kim, H.K.; Yun, Y.K.; Kang, S.J.; Kim, K.T.; Kim, B.D.; Kim, E.J.; Choi, Y.M. Sensory quality characteristics with different beef quality grades and surface texture features assessed by dented area and firmness, and the relation to muscle fiber and bundle characteristics. Meat Sci. 2018, 145, 195-201. [CrossRef] [PubMed]

65. Chail, A.; Legako, J.F.; Pitcher, L.R.; Ward, R.E.; Martini, S.; MacAdam, J.W. Consumer sensory evaluation and chemical composition of beef gluteus medius and triceps brachii steaks from cattle finished on forage or concentrate diets. J. Anim. Sci. 2017, 95, 1553-1564. [PubMed]

66. Coelho, D.; Pestana, J.; Almeida, J.M.; Alfaia, C.M.; Fontes, C.M.; Moreira, O.; Prates, J.A. A high dietary incorporation level of Chlorella vulgaris improves the nutritional value of pork fat without impairing the performance of finishing pigs. Animals 2020, 10, 2384. [CrossRef] [PubMed] 